\title{
Measuring Language Effectiveness In Arabic Expression Through Analysis of Ellipsis (Al-Hadzf)
}

\author{
Afnan Arummi ${ }^{1}$, Eva Farhah $^{2}$, Reza Sukma Nugraha ${ }^{3}$ \\ \{afnanarummy85@staff.uns.ac.id ${ }^{1}$, evafarhah@staff.uns.ac.id ${ }^{2}$, reza.sn@staff.uns.ac.id $\left.{ }^{3}\right\}$ \\ 1,2,3 Arabic Literature Faculity of Humanities Sebelas Maret University, Surakarta Indonesia
}

\begin{abstract}
The effectiveness of language can be stated by presenting an ellipsis element in a utterance. With this element, an utterance in any language will be felt simple, easy, and convoluted, because it will eliminate and sort out the level of language which must be prioritized and which does not need to be raised, and where its existence is sufficient with a marker or context (siy $\bar{a} q)$. An ellipse is an element that cannot be separated from any linguistic system. In all linguistic systems, basically it has the same principle when defining ellipsis, which is a process of elimination or dissolution of one constituent contained in a speech. But each linguistic system has its own uniqueness and characteristics according to the universal linguistic nature. Sokah [1980: 82] states that one of the languages that has the most methods compared to other languages in the world is Arabic. This language has solid rules and is not easily changed in terms of morphology and syntax, although from the other side experiencing important changes [Hadi, 2018: 7]. The indicator of a very complex linguistic system can also be seen in its elipsis element, where it is found in almost all of its subsystems. In Arabic, elipsis is better known as the Hadzfwhich definition is generally not quite different from other definition in other languages. But specifically it has its own characteristics and uniqueness. This paper explores and analyzes the principle of ellipse in Arabic which has a very rich linguistic system by outlining the basic thinking of Arab linguists about the element, why, what is the purpose specifically and effectively as to whether this element is unique to Arabic in language activities?. This research is a descriptive analytic library research. Descriptive means describing the basic concepts of research objects that are being focused. While analytic means giving notes or analyzes of these objects based on the approaches and theories used. Researchers in this study used several methods, first collecting all data from several primary sources. second, analyzing these data with the main technique for direct elements, namely by classifying linguistic elements based on their categories and functions. The main technique will be followed by several advanced techniques to sharpen the analysis. Third, the presentation of research results adjusted to the format of standard scientific writing.
\end{abstract}

Keywords: ellipsis, $H a d z f$, Arabic, effectiveness, language.

\section{Introduction}

Communication is one of the basic human needs to convey a message. Communication is usually manifested in the form of language activities, meaning that language becomes a tool for compiling and assembling the messages to be conveyed from speakers to speech partners, so that the messages conveyed can be well received and understood. Judging from the origin of the terminology, the term communication is taken from the Latin word communis which 
means 'same'. The word is linear with several other words such as communico or communicare which means to make common [Mulyana, 2000: 41]. Based on the meaning of the terms above, it shows that the common understanding of a message between speakers and speech partners is absolutely necessary. Furthermore, a thing that is highly expected by someone who conducts communication activities or in a scope that can be limited, namely speaking activities, is that the conversation takes place effectively and efficiently. The indicator that determines the effectiveness and efficiency of a conversation is the speech communicated by the speaker can be understood by the partner [Ainin, 2010: 49].

In an effort to make effective and efficient communication, Grice [1975 in Saifullah, 2018: 17-21] suggests two basic rules related to the use of language, namely the principle of cooperation and four thimbles (maxim) conversations which include quantity, quality, relevance, and method. In quantity thimbles, speakers should provide appropriate information which includes (a) information must be as informative as needed, (b) information does not exceed what is needed. Furthermore, in the quality thimble stated, that the speaker seeks that the information conveyed is true and based on facts without lies, meaning that what is conveyed is believed to be true and does not say a proof that the truth is less convincing or based on assumptions. The content of the thimble of relevance is that the words conveyed by speakers should have relevance to what is needed. This means that there must be a match between what was asked or what was discussed with the answer or response. Meanwhile, the way thimble refers to the efforts of the speaker so that his words are easy to understand, clear, concise and avoid ambiguity in his words. Leech (1983) argues, for speakers should avoid the existence of (a) vague statements, (b) inaccuracy, (c) the effort of the conversation is brief but solid and (d) the effort for speakers to speak regularly.

By paying attention to the principle of cooperation and the four thimbles (maxims) of the conversation above, a conversation between two people or groups will run effectively and efficiently. Furthermore, Wilbur Schramm in his work entitled How Communication Works [in effendy, 1990: 32-33], reveals what is called "the condition of success in communication" which can be summarized briefly as follows (a) The message must be designed and delivered in such a way that it can attract the attention of the intended target, (b) The message must use signs that are directed towards the same experience between the communicator and the communicant (speaker and partner), so that they can be understood, (c) The message must generate needs private communicant, and suggest several ways to obtain those needs, (d) the message must suggest a way to obtain these needs that are appropriate for the situation where the communicant group is at the time he was moved to provide the desired response. If communication communicated is not in accordance with the interests of the communicant, it will face difficulties.

It can be observed from Schramm's statement above, that the way the message is delivered is very influential on the effectiveness of the communication process. A good way in delivering message will make it easier for the partner to receive and understand it. Based on this, one way to deliver good and effective messages in communication and language activities can be reached by using elipsis elements in speech. By using this element, an utterance in any language will be felt easy, simple, and not complicated, because it will eliminate and sort out the level of language which must be prioritized and which does not need to be raised, and its existence is sufficient with a marker or context (siyāq). This is in line with the principle of cooperation and four conversational thimbles and Schramm's opinions above.

One language that has the most methods compared to other languages in the world is Arabic [Sokah, 1980: 82]. This language also has its own peculiarities or characteristics from other languages in the world [Taufiq, 2018: 23]. From some peculiarities or characteristics of 
Arabic as stated by Mahmud Ahmad Al-Sayyid [1997: 220-231] that its superiority in the aspect of the style of language $(u s l \bar{u} b)$ is concise $\left(i^{\prime} j \bar{a} z\right)$ but solid, the redaction is precise and has a clear intention. Based on the continuity of meaning and not divided into two, namely the style of rhetorical language and the style of figurative language. One style of rhetorical language is elipsis which in Arabic is known as al-Hadzf and in Balaghah's study this element is harmonized with badi' ikhtifä' [Taufiq, 2018: 166].

Therefore, this paper will analyze the elliptical principle which is limited in the Arabic grammatical system which according to the author has a very rich and complex linguistic system by outlining the basic thinking of the Arabic linguists about the element, why and what purpose is it specifically and effectively maintain the uniqueness of Arabic in language activities. In order to focus on the object of this research, the author limits it to two fundamental aspects which include (1) the notion of elipsis in Arabic and (2) how elipsis can be used as a measure of language effectiveness.

\section{Research Method}

This research is a descriptive analytical library research. Descriptive means describing the basic concepts of research data objects that are being focused. Whereas analytic means describing a problem or focus of study into parts (decomposition) so that the order in which something is decomposed looks clear and bright [Satori and Komariah, 2014: 200]. Analytic also means the process of organizing and sorting data into patterns, categories and basic description units so that themes can be found and work hypotheses can be formulated as suggested by data [Moleong, 2000: 103]. In addition, according to the analytic writer also means the process of providing notes, analysis and interpretations of the data based on the approaches and theories used. In more detail, the author in this study uses several methods which include data collection, data analysis, and presentation of the research results as follows:

The first is collecting all data from primary and secondary sources. The sources of primary data from this study are words [lofland and lofland 1984 in Moloeng, 2000: 112]. In relation to the object of this research, the author uses a book by Dr. 'Ali Abu Al-Makārim entitled Ushūl a't-Tafkīr a'n-Nachwi published by Dār Gharīb Kairo in 2006 and a book titled $A^{\prime} n-N a h w u$ Al-'Araby as many as six volumes by 2007 Ibrāhīm Ibrāhīm Barakāt printed and published by the publisher Dār A'n-Nasyr Li Al-Jämi'ah, Cairo. The first book discusses in detail the basic ideas and concepts of grammar in Arabic. This book also offers an explanation of the basic matters relating to the formation of terms in the Arabic syntactic system and the philosophical foundation behind their formation including matters relating to ellipsis (alHadzf). The second book contains comprehensive main data that presents scientific data from this study. While secondary data consists of other written sources such as journals, dictionaries, e-books and online literature sources related to the title of this research. This data collection method is supported by one data collection technique namely documentation technique.

Second, the method used in this study is data analysis method. This study uses language text analysis with a stylistic approach. Nurgiyantoro [2014: 78] argues that stylistics is between linguistics and aesthetics. Stylists are at the linguistic level because they are literary objects whose main component is language. Whereas, stylistics is said in the aesthetic level because the main purpose of literature is an aesthetic effect. Furthermore, at the technical level 
the data that has been collected will be analyzed with the main technique for the direct element, namely by classifying linguistic elements based on their categories and functions. The main technique will be followed by several advanced techniques to sharpen the analysis. Third, the presentation of research results adjusted to the format of standard scientific writing.

\section{Results and Discussion}

\subsection{Elipsis in Arabic}

Elipsis in Arabic is known as al-Hadzf [El-Dachdach, 2000: 123]. The phenomenon of al-Hadzf in the study of Arabic syntax falls into the phenomenon of takwil. Takwil itself can be interpreted as the process of explaining or interpreting something [https://kbbi.kemdikbud.go.id]. This phenomenon is like the forms of takwil in other Arabic grammatical studies born of the efforts of Arab linguists to validate existing texts (nushūsh) which are assumed by laws in the Arabic grammatical rules.

The Hadzf process is implemented with the assumption of eliminating the elements in the text that are not displayed in it. From this process linguists have arrived at an attitude that they seek to harmonize the rules that have been set in the grammar of Arabic and texts (nushūsh) which are assumed to be incompatible with these rules.

Ibn As-Sirāj [in Abu Al-Makārim, 2006: 246] has a different view. He argues that Hadzf is devoted to the conditions of the exile 'amil and determines the existence of $m a$ ' $m \bar{u} l$ as the law of $i$ 'rab. So if the law changes after the $\operatorname{Hadzf}$ (ellipsis), it can be associated with another term namely expansion of takwil or ittisa $\bar{a}$ '. According to him, expansion of takwil or ittisā' is part of Hadzf. The difference between the two lies in the point of view which used. The object of Hadzf is located in the text, meaning the Hadzf terminology is used in a text which experiences one of its elements dissolved. Whereas the ittis $\bar{a}$, object is located in the takwil process or the interpretation of the element that has been dissolved. However, most Arab linguists do not focus on the differences between the two terms. They make Hadzf as an element which includes two conditions, namely the change of $m a^{\prime} m \bar{u} l$ and determine its existence as the law of i'rab (word end of tithe) in the order of sentences. In the sense that $H a d z f$ is to eradicate some of the elements contained in the text while maintaining the form of the form or changing the form of the charity to adjust it to the new position or position in the text. Hadzf in the context of the above understanding is closely related to the concept of taqdi $r$ (interpretation) in certain conditions. Based on this understanding, the Hadzf also includes the meaning of taqdīr, which is the process of interpreting known hadith elements through clues that indicate their existence in sentence order. Thus the Hadzf and taqdir phenomena in the study of Arabic syntax show one style of language that is limited to the style of language based on the process of takwil (interpretation). In addition, the phenomenon also focuses on efforts to restore the elements that are imprinted in the sentence structure to their original form [Abu Al-Makārim, 2006].

\subsection{Divison of Hadzf}

The scope of the study of Hadzf is very complex and broad, because it includes all elements in the study of Arabic syntax ( $\left.a^{\prime} n-n a c h w u\right)$. The study covers the harakah i'räbiyyah or the final sign of every word that shows the language function to the problems of phrases, 
clauses and sentences. For this reason, in this study the focus of the discussion will be on the three conditions [Abu Al-Makārim, 2006]: (1) Hadzf of the harakah i'räbiyyah (the final sign of every word), (2) Hadzf of clause or sentence, and (3) Hadzf some elements of clause or sentence.

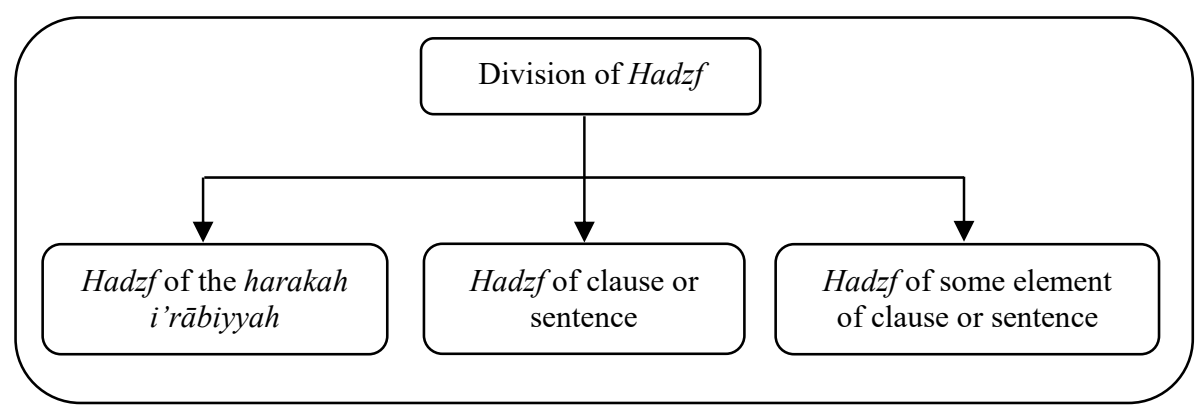

Fig. 1. Division of Hadzf (Ellipsis in Arabic Syntax)

\section{Harakah I'rābiyyah}

Hadzf of the harakah i'räbiyyah in the study of Arabic syntax occurs in many circumstances. Harakat or sign can be interpreted entirely or only partially. Among the conditions of the harakat interpreted for its existence can be seen in the following description:

First, clauses or sentences (jumlah) that occupy and fill in a function such as the function of a single nominal (ism mufrad). Basically harakah i'rabiyyah on singular nominal (ism mufrad) will appear in the end. Some clauses or sentences include:

a. Clause (jumlah) that occupies the Predicate function (khabar)

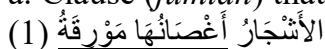

al-asyjāru aghshānuhā mauriqatun [Ni'mah,1986]

The arrangement underlined above is a nominal clause form (jumlah ismiyyah) which is composed of subject-predicate construction (mubtada'-khabar) which occupies or fills the function as a function composed of a single noun form (ism mufrad). Harakah I'rābiyyah from the construction was carried out and only interpreted in a nominative state ( $\mathrm{rafa}^{\prime}$ ) as if the form of a single noun (ism mufrad), serves as a predicate (khabar) for the subject

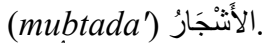

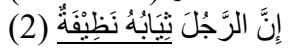

Inna ar-rajula tsiyābuhu nadzīfatun [Ni'mah, 1986]

The arrangement underlined above is a nominal clause form (jumlah ismiyyah) which is composed of subject-predicate construction (mubtada'-khabar) which occupies or fills the function as a function composed of a single noun form (ism mufrad). Harakah I'rābiyyah from the construction was carried out and only interpreted in a nominative state ( $r a f a ')$ as if in the form of a single noun (ism mufrad). The clause functions as a predicate (khabar inna)

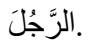

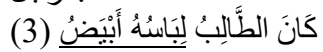

Kāna a'th-thàlibu libāsuhu abyadhu [Ni'mah,1986]

The arrangement underlined above is a nominal clause form (jumlah ismiyyah) which is composed of subject-predicate construction (mubtada'-khabar) which occupies or fills the function as a function composed of a single noun form (ism mufrad). Harakah I'rābiyyah from the construction was carried out and only interpreted in an accusative state (nashab) as if 
in the form of a single noun (ism mufrad). The clause functions as a predicate (khabar kāna) الطُّالِبُ.

b. Clause (jumlah) that occupies the adverb function (chāl)

(4) وَلَاتَمْنُنْ تَنْنَكْنْرُ

walā tamnun tastaktsir [Abu Al-Makārim, 2006]

The underlined arrangement above is a verbal clause (jumlah fi'liyyah) which is composed of subject-predicate construction $\left(f i^{\prime} l-f \bar{a} ' i l\right)$ which occupies or fills the function as a function composed of a single nominal form (ism mufrad). The clause functions as adverb $(c h \bar{a} l)$. Harakah I'räbiyyah from the construction was completed and only interpreted in an accusative state (Nashab) as if in the form of a single noun (ism mufrad).

c. Clause (jumlah) that occupies object function ( $m a f^{\prime}$ 'ul bih)

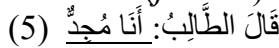

Qāla a'th-thālibu: anā mujiddun [Ni'mah,1986]

The arrangement underlined above is the arrangement of words (aqwāl) which is stated

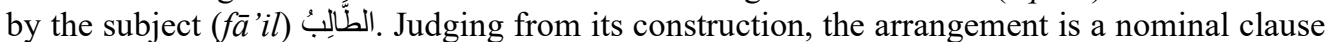
(jumlah ismiyyah) which is composed of subject-predicate construction (mubtada'-khabar) which occupies or fills the function as a function composed of a single noun (ism mufrad). Harakah I'rābiyyah from the construction was carried out and only interpreted in an accusative state (nashab) as if in the form of a single noun (ism mufrad) and functioned as an object (maf'ül bih). In Arabic, each arrangement of words (aqwāl) as above always occupies the function of an object.

d. Clause (jumlah) that occupies function of mudhäf ilaih

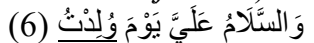

Wa's-salāmu 'alayya yauma wulidtu [Abu Al-Makārim, 2006]

Clause وُ ولذَتُ 'is a verbal clause (jumlah fi'liyyah) which is composed of subject-predicate construction ( $f{ }^{\prime} l-n \bar{a}^{\prime} i b u l f \bar{a}$ ' $\left.i l\right)$ which occupies or fills the function as a function composed of a single nominal form (ism mufrad). Harakah I'räbiyyah from the construction was erased and only interpreted in a genitive state (jarr) and functioned as mudhäf ilaih (the arrangement based on the previous word يَوَْ).

e. Clause (jumlah) that occupies apodosis function (jawāb syarthiy)

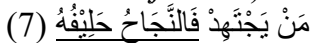

Man yajtahid fa'n-najāchu chalīfuhu [Ni'mah,1986]

The arrangement underlined above is a nominal clause (jumlah ismiyyah) which is composed of subject-predicate construction (mubtada'-khabar) which occupies or fills functions as functions composed of a single noun (ism mufrad). The clause functions as apodosis (jawāb syarthiy). Harakah I'räbiyyah from the construction was erased and only interpreted in an apocopative state (jazm) as if the arrangement was in the form of a single noun (ism mufrad)

f. Clause (jumlah) that occupies function of tābi'(subordinate clause) for clause (jumlah) which becomes function

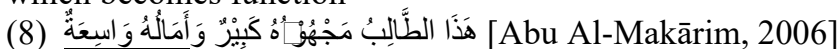

hādzā a'th-thālibu majhūduhu kabìrun wa amāluhu wāsi'atun

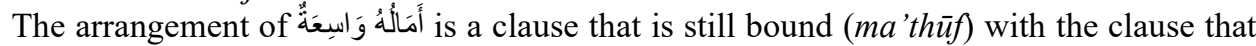

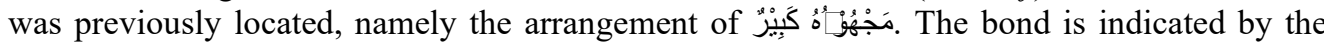
particle $و(w a u)$. Harakah I'rābiyyah from the construction was carried out and was only interpreted in a state of nominative ( $r a f a ')$. The construction functions as a predicate (khabar)

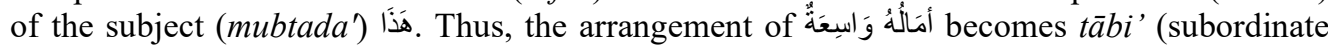
clause) which is in the same rules and position as the clause followed. 
Second, Hadzf or the dissolution of the word i'räbiyyah also applies to the form of mashdar mu'awwal (infinitive). The omission or ellipsis includes three conditions which are nominative ( $r a f a$ '), accusative (nashab), genitive (jarr).

a. The nominative ellipsis $(r a f a ')$ is shown in the following arrangement:

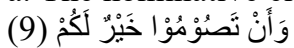

wa an tashūmū khairun lakum [Abu Al-Makārim, 2006]

The arrangement of وَأَنْ تَصَوْْمُوْا is a form of mashdar mu'awwal (infinitive). This arrangement fills the subject function (mubtada'). As for Harakah i'rābiyyah in this arrangement it is carried out and can only be interpreted as being, namely in a nominative state $\left(\mathrm{rafa}^{\prime}\right)$.

b. The ellipsis of the accusative character (nashab) is shown in the following arrangement:

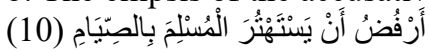

arfudhu an yastahtura almuslima bi'sh-shiyāmi [Abu Al-Makārim, 2006]

The composition of أَنْ يَنْنَهُُْرُ in a form of mashdar mu'awwal (infinitive). This arrangement becomes an object (maf'ūl bih) of the predicative arrangement of consists of subject-predicate $\left(f i^{\prime} l-f \bar{a}^{\prime} i l\right)$. The Harakah i'räbiyyah actually in this arrangement is accusative (nashab). However, because the form is not a single nominal (ism mufrad), the gift is set aside and can only be interpreted as being, namely in an accusative state (nashab).

c. The ellipsis of the genitive (jarr) is shown in the following arrangement:

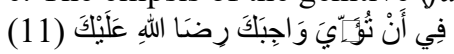

fì an tu'addiya wājibaka ridhal'llāhi 'alaika [Abu Al-Makārim, 2006]

The arrangement of أَنْ تُوَّْيَ is a form of mashdar mu'awwal (infinitive). Harakah i'räbiyyah in the arrangement beginning with the particle في (fî) is basically genitive (jarr). However, because the arrangement is formed not from a single noun (ism mufrad), it is set aside and can only be interpreted as being in a genitive state (jarr).

Third, Hadzf or ellipsis of the harakah i'rābiyyah at al-asmä' al-maqshürah. In the case of this form, its occurrence occurs in three conditions, namely nominative ( $r a f a$ '), accusative (nashab), genitive (jarr).

Fourth, Hadzf of ellipsis of the harakah i'rābiyyah at al-asmā' al-manqūshah. As in the form of al-asmā' al-manqūshah, the ellipsis of $i^{\prime} r \bar{a} b$ applies to two circumstances, namely nominative (rafa) and genitive (jarr).

Fifth, Hadzf or ellipsis of $i^{\prime} r a \bar{b}$ at al-asmā' al-mabniyyah (indeclinable noun) occurs in all forms of nouns. Harakah i'rābiyyah in this form can be said not to appear at all. Even if this noun is placed in a sentence structure and is attached to a function, the gift remains the same and does not change. Changes that occur only in the form of interpretation of Harakah i'rābiyyah which follows its linguistic functions.

sixth, Hadzf or ellipsis of harakah i'rābiyyah for al-fi'l al-mudhāri'al-mabniy (indeclinable imperverct verb). The form of harakah at the end of this verb is basically always in the state of sukūn (i) and fatchah (j). According to the Arabic linguists, the interpretation of the i'räbiyyah's address covers three conditions, namely nominative ( $r a f a)$, accusative (nashab) and genitive (jarr).

seventh, Hadzf or ellipsis of harakah i'räbiyyah for al-fi 'lal-mudhāri'al-mu'tall (vocalic verb). In this case, if the letter 'illah in the verb is alif, then the interpretation of the pronounced i'rābiyyah must include two conditions, namely nominative $\left(\mathrm{rafa}^{\circ}\right)$ and accusative (nashab). However, if the letter form 'illah in the verb is wau and $y \bar{a}^{\prime}$, the interpretation of the meaning of $i^{\prime} r \bar{a} b$ which has been completed includes only one condition, namely nominative $\left(r a f a a^{\prime}\right)$. 


\section{Partial ellipsis (Hadzf) of Clause or Sentence Elements}

Arab linguists have the view that ellipsis (hadzf) on some elements of clause or sentence occurs at all levels in the study of Arabic syntax, so that there is no linguistic element in it except relating to ellipsis (hadzf). Some linguistic elements that experience lapse (hadzf) in some clauses or sentences include [Abu Al-Makārim, 2006]:

(1) Mubtada' and khabar and all the verbs included in the two elements, (2) mafá'ill or all object forms and information, (3) idhäfah (genitive phrase), (4) maushül (relative), (5) qasam (Jurative), (6) syarth (conditional sentence), (7) 'athaf (conjunction), and (8)'a'tid (antecendent).

In each of these elements, several clauses or sentences are applied. Even lapse can occur in certain parts that were originally in the arrangement of clauses or sentences. The process of analyzing the parts that are applied in a clause or sentence arrangement reveals important facts in the research of the Arabic Syntax. These facts include:

First, relating to what is considered to have dissolution from the clause or sentence section. The Arab linguists argue that the dissolution includes three classes of words in Arabic, namely noun (ism), verbs $\left(f^{\prime} l\right)$ and particles (charf). In the case of noun (ism) and verb $\left(f^{\prime} l\right)$ it is always associated with the positions and functions of the two which differ in the arrangement of clauses or sentences, as well as related to particles (charf) and their kinds.

second, relating to the rules governing the parts of the type of lapse. In this case, two views are found:

a. The first view: grammatical work concepts which certainly require the presence of three important elements in it, namely: 'ämil, ma'mūl, and harakah i'räbiyyah. If there is no one of these elements in the sentence structure, the steps taken are estimating things that do not exist. For example, if the clause or sentence arrangement has 'ammil while the ma'mūl does not exist, its existence must be estimated through interpretation based on the clues contained in the arrangement, and vice versa.

b. The second view is the scope of Arab linguists' thinking about the sentence system. The scope is based on the existence of attributions made up of two parts namely musnad (another term for the predicate) and musnad ilaih (the other term for the subject), whether the musnad appears in sentence form or is simply a relation indicated by the prepositional phrase arrangement (zharf and jarr-majrür). Arab linguists think that it shows the connection between the two.

Both of these views have greatly influenced the division of forms of dissolution of some element of a sentence or sentence. When Arab linguists found many perfect structures as indicators of a sentence structure, but did not meet the requirements of attribution, namely the presence of two main parts, namely musnad and musnad ilaih. Therefore, they were forced to estimate their existence in the sentence structure.

3. Sentence Ellipsis

In Arabic, it is known that some terms denote an order, namely jumlah, kaläm and tarkīb. Tarkīb terminology refers to the order of more than one jumlah or clause, whether the order is part of another sentence or one whole sentence, as long as the structure does not include the kaläm stage. This means that the tarkīb arrangement is only part of the kalām. Thus kalām is a complete arrangement and can be matched with sentences. Concerning the erasure of sentences in the hadzf phenomenon can be understood as the dissolution of each clause in one sentence, either the erasure of one clause or several clauses [Abu Al-Makārim, 2006].

a. Jumlah

The Arab linguists argue that total ellipsis occurs in certain conditions. The following is a detailed description: 
1) Qasam (Juratif). This clause is a clause that shows an oath. This clause consists of three main elements, namely the oath clause which begins with the marking and the answer clause. Ellipsis of this clause can be done by passing the oath clause part at a time and the answer clause at another time.

2) Syarth (Conditional). This clause is also called a requirement clause. This clause also consists of the main elements, namely conditional markers, requirements clauses and answer clauses. The ellipsis of this clause can be done by just disposing a condition clause at one time and the answer clause at another time, or the two clauses are put together together and only mention the conditional markers.

3) 'Athaf (conjunction): this clause is indicated by a conjunction marker. Ellipsis of this clause can be done with ellipsis a clause that is located before the marking partially or together with the marker. Similarly, impingement can be carried out by applying a clause located after the conjunction marker or together with the marker.

In addition to the three conditions above, the ellipsis of other jumlah arrangements also apply to such arrangements such shillah, chāl (adverb), maf'ūl bih (objek), mashādir, zhurūf and jār-majrūr.

b. Kalām

Arabic linguists argue that kalām lapses occur in five circumstances. that is:

1) If it is located after the particle answers (churüf jawāb). For example:

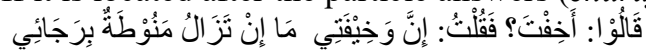

qālū: a khifta? faqultu: inna wa khīfatī mā in tazālu manūthatun birajā't̄ [Abu AlMakārim, 2006]

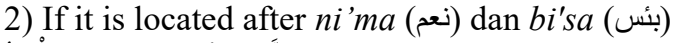

إِنَّا وَجَدْنَاهُ صَابِرًا انِعْمَ الْعَبْدُ

innā wajadnāhu shābiran ni'mal 'abdu [Abu Al-Makārim, 2006]

3) If it is located after vocative particles (churū nidā')

يَا لَيْتَ قَوِْْي يَعْلَمُوْنَنَ

yā laita qaumī ya 'lamūna [Abu Al-Makārim, 2006]

4) If it is located after a conditional particle in (إن (إن)

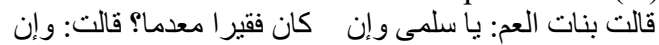

qālat banātu'l- 'ammi:yāsalmāwa in kānafaqūranmu'diman?qālat: wa in. [Barakāt,2007]

In the arrangement located after the particle إن (in) above, there is a conditional sentence arrangement in which the clause requirements and the answer clause are applied, but the existence of the two components of the sentence can be interpreted based on the instructions contained in the context of the order. The interpretation of the arrangement

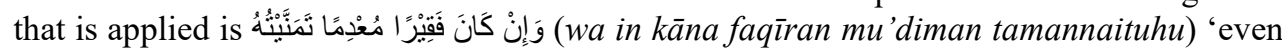
though he is poor and not, I want it.' Thus, if the applied structure is shown, the arrangement becomes:

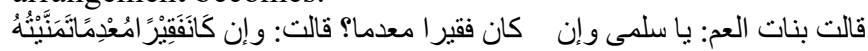

qālat banātu'l- 'ammi: yā salmā wa in kāna faqūran mu'diman? qālat: wa inkāna faqūran mu'diman tamannaituhu

5) In an arrangement that resembles the intended amtsāl arrangement to assert an affirmation إفْعَلْ هَذَا إِمَّا لَاِ

if'al hādzā immā lā [Abu Al-Makārim, 2006]

Judging from the structure, the arrangement above is one form in the conditional arrangement. In the outline of the sentence, there is an arrangement that is applied. The interpretation of the sentence is إِنْ كُنْتَ لاَ تَفْعَلُ غَيْرَهُ فَافْعَلْهُ (in kunta lā taf'alu ghairahu faf'alhu) 'if you don't do this job, then do another job'.The interpretation is based on the 
clues of the existing sentence. By showing the arrangement of sentences that are set, the arrangement becomes as follows:

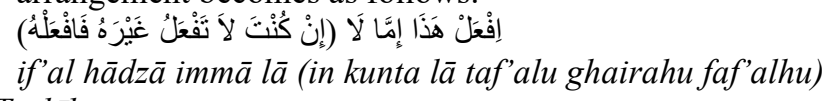

Tarkī with the definition mentioned above, namely an arrangement of more than one jumlah or clause basically does not have special conditions. However, some examples of this arrangement can be mentioned as follows:

Word of Allah SWT:

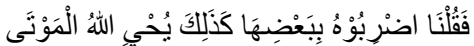

$$
\begin{aligned}
& \text { qulnā'dh-ribūhu bi ba'dhihā kadzālika yuchȳ̄llāhul mautā [Abu Al-Makārim, 2006] }
\end{aligned}
$$

This arrangement is a tarkīb arrangement. Ellipsis in this arrangement occurs in three interpretable clauses, consisting of clauses فضربوه, فحي , فقلنا Thus, if the clauses are included in the composition of the sentence above, then the arrangement becomes:

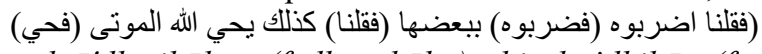

In addition to the example above, it can be seen in the following arrangement: Word of Allah SWT:

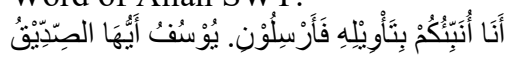

anā unabbi'ukum bita'wīlihi fa arsilūni. yūsuf ayyuhū'sh-shidd̄̄qu [Abu Al-Makārim, 2006]

In the tarkīb arrangement there are lapses of several clauses. The clauses that can be interpreted as being in this arrangement consist of فأرسلون إلى يوسف لأستعبره الرؤيا, فأرسلوه, فاتاه,

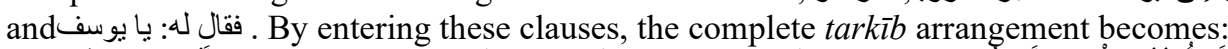

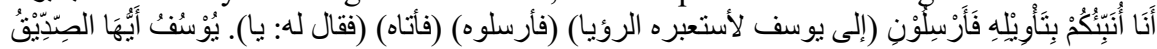

anā unabbi'ukum bita'wīlihi fa arsilūni (ilā yūsufa li asta 'birahu'r-ru'yā. fa arsalūhu. fa atāhu. Faqāla lahu: yā) yūsuf ayyuhū'sh-shiddīqu.

From the language data that has been described, it can clarify the rationale for the causes of the al-hadzf phenomenon in the Arabic grammar system. The basic ideas can be summed up in two things as follows:

1. The divisions formulated by the Arabic linguists in the phenomenon of al-hadzf are basically borrowing from the thinking of the science of kalām (philosophical discipline to seek the principles of Islamic theology through dialectics). Thought in this science, if examined further influenced by Greek philosophy. So that it can be said that existing divisions are not based solely on linguistic and grammatical phenomena.

2. Reality $a l-h a d z f$ helps explain language errors. This is due to its linearity with the concept of taqdīr which functions to interpret the phenomena of language that are not yet clear until it can be understood the reason behind it.

\section{Conclusion}

Based on the explanation above, it can be concluded that the Ellipsis which is known in Arabic as al-hadzf is included in the phenomenon of takwil or interpretation of something. The term al-hadzf is also linear with the terms ittisā 'and taqdīr. The study of al-hadzf arises from the efforts of Arabic linguists to examine the validity and rigidity of the structure of the texts (nushüsh) in Arabic with the laws in the applicable Arabic grammatical rules. Furthermore, it is also concluded that ellipsis or al-hadzf can be used as a measure of language effectiveness. 
This can be proven by the ability of al-hadzf to eliminate elements that are not prioritized in the sentence structure. One language phrase or message that may consist of three elements, can be conveyed by only expressing one or two elements. Because each element is always bound by a clue based on the context (siy $\bar{a} q$ ) of the sentence, so that when other elements are set apart and only one element is left in the sentence structure, one element can represent the meaning of the other elements

\section{Acknowledgements}

Thank you profusely, the researcher conveyed to the Institute for Research and Community Service (LPPM) Universitas Sebelas Maret, which has given trust and opportunity and research funding support to the author so this research with the scheme of Capacity Building Research for Scientific Publications, contract number 516/UN27.21/PP/2019 can be carried out well. The researcher also expressed her gratitude to the Arabic Literature Study Program UNS who had provided the literature needed by the researcher so that this article could be completed well.

\section{References}

[1] Ainin, Muh. (2010). Fenomena Pragmatik dalam Al-Quran: Studi Kasus Terhadap Pertanyaan. Malang: Penerbit Misykat

[2] Abu Al-Makārim, Ali. (2006). Ushūl a't-Tafkīr a'n-Nachwi. Kairo:Dār Gharīb.

[3] Al-Khuli, Muhammad Ali. 1982. A Dictionary of Theoretical Linguistics. First edition. Lebanon: Librairie Du Liban

[4] Barakāt, Ibrāhīm Ibrāhīm. (2007). A'n-Nahwu Al-'Araby. Cetakan pertama. Kairo: Dār A’nNasyr Li Al-Jāmi'ah.

[5] Effendy, Onong Uchjana (1990). Dinamika Komunikasi. Bandung: PT Remaja Rosdakarya.

[6] El-Dachdach, Antonie. (2000). A Pocket Dictionary of Arabic Grammatical Nomenclature. Beirut: Librairie du Liban Publishers.

[7] Grice, H. P. (1975). Logic and Conversation. Dalam Petter Cole dan Jerry L. Morgan (Eds.), Syntax and Semantics, Volume 3. New York: Academic Press

[8] Hadi, Syamsul, et.al. 2018. Menggagas Formulasi Baru tentang Bahasa, Sastra dan Budaya Arab. Yogyakarta: Idea Press Yogyakarta

[9] Leech, Geoffrey. (1983). Principles of Pragmatics. New York: Longman Linguistics Library

[10] Mulyana, Deddy. (2000). Ilmu Komunikasi. Bandung: PT Remaja Rosdakarya.

[11] Moleong, J. Lexy. (2000). Metodologi Penelitian Kualitatif.

[12] Nasir, Mohd Shahrizal. (2017). "Elipsis (al-Hadhf) dalam al-Quran sebagai Satu Petunjuk Ketinggian Bahasa Arab Kalamullah". Jurnal MANU Jurnal Pusat Penataran Ilmu dan Bahasa Bil. 25/2017

[13] Nurgiyantoro, Burhan. (2014). Stilistika. Yogyakarta: Gadjah Mada University Press.

[14] Ni'mah, Fuad. (1986). Mulakhkhash qawā'id al-lughah al-'arabiyyah. Damaskus: Dār alchikmah

[15] Saifullah, Aceng Ruhendi. (2018). Semantik dan Dinamika Pergulatan Makna. Jakarta: Bumi Aksara.

[16] Sokah, Umar Asasuddin. 1980. Kalimat Kondisional Bahasa Inggris, Arab, dan Indonesia (Suatu Studi Perbandingan). Jurnal Al-Jami'ah vol no 22. Yogyakarta: Universitas Islam Negeri Sunan Kalijaga.

[17] Satori, Djam'an dan Qomariah, Aan. (2014). Metodologi Penelitian Kualitatif. Bandung: Alfabeta

[18] Taufiq, Wildan. (2018). Metode Penelitian Bahasa Arab. Bandung: PT Refika Aditama.

[19] https://kbbi.kemdikbud.go.id 